\title{
Cytotoxic Effect of Some \\ Furanosesquiterpenes from Balsamodendron myrrha Nees. Oleo-gum-Resin on Brine Shrimp (Artemia salina) Larvae
}

\author{
Ayesha Asif1, M. Asif Saeed²* \\ 1 Faculty of Pharmacy, University of Central Punjab, Lahore, Pakistan. \\ 2Department of Pharmacognosy, University of the Punjab, Lahore, Pakistan.
}

\begin{abstract}
Furanosesquiterpenes from Balsamodendron myrrha oleo-gum-resin were assessed for their cytotoxic effect. Six Furanosesquiterpenes from hexane insoluble part of EtOH extract of $B$. myrrha oleoresin was separated, purified by column, preparative TLC and recrystallization. These were identified by comparative spectroscopic data. Cytotoxic effect of these compounds was carried out on brine shrimps' (Artemia salina) larvae (nauplii), evaluated by $\mathrm{LD}_{50}$ after compared with positive controlled colchicine. Six isolated furanosesquiterpenes demonstrated cytotoxic effect against brine shrimps' larvae compared with colchicine. Four sesquiterpenes, compound-1 (myrracadinol-A), compound-2 (myrracadinol-B), compound-5 (furanodiene-6-one) and compound-6 (2-methoxy-furanodiene) was the most active compound compared with compound-3 (furanodiene) and compound-4 (2-acetoxy-furanodiene).From the hexane insoluble part of ethanol extract of $B$. myrrha oleo-gum-resin, four furanosesquiterpenes were noxious while other two were mild harmful to the brine shrimps' larvae.
\end{abstract}

Keywords: Cytotoxic effect, furanosesquiterpenes, oleo-gum-resin, Balsamodendron myrrha, $\mathrm{LD}_{50}$.

\section{INTRODUCTION}

Members of the family Burseraceae including Balsamodendron myrrha Nees., exude resins in peculiar and definite cavities or passages with a complex chemical nature ${ }^{1-3}$. Some investigators trusted that these resins were aerobiotic prod-

\footnotetext{
*Corresponding author: Mustafa Nadhim Owaid, e-mail: moasif1605@yahoo.com Ayesha Asif ORCID Number: 0000-0002-1387-735X M. Asif Saeed ORCID Number: 0000-0002-6003-7871 (Received 30 December 2019, accepted 08 January 2020)
} 
ucts of essential oils ${ }^{3,4}$. Resin occurs solitary or in combination with volatile oils or gums $^{1,3}$. When they are in the form of a consistent mixture with volatile oil, they were often described as oleoresins. Oleoresins also occur in admixture with gums which were then called oleo-gum-resins ${ }^{1,3-5}$. It has been investigated that the members of the family Burseraceae yielded resins as oleo-gum-resins in resin canals, present in their phloem which were established schizogenously or as schizolysigenous cavities ${ }^{1,3,4}$. An appreciable amount of oleo-gum-resin was accumulated in such cavities. The internal secretory system of the resin canals was also extended over the bark, pericycle, secondary cortex and medullary rays of the trees ${ }^{1,3,4}$.

Many species of this family are economically valuable on account of their resins which have been exploited medicinally, but many species are used mainly in incense and perfumes ${ }^{1-5}$. The most important were frankincense or olibanum (from Boswellia species) and myrrha (from Balsamodendron or Commiphora species). These oleo-gum-resins were procured by tapping or by cutting their barks. These were further processed and coalesced with various seed's or root's oils to make versatile incense ${ }^{6}$. Both these species were native to Northeast Africa (Somalia and Ethiopia) and Arabia (Oman and Yemen), but their dispersion and utilization have been extended over to Indo-Pak region and China ${ }^{6-8}$. The resins from these trees were exploited in Indian Ayurvedic medicines and in Chinese herbal medicines to regale various complaints. In Indian and in Chinese oriental medicines small doses of these resins were appreciated for encouraging blood flow and for crusading the 'qi', i.e., the 'life force' or 'spiritual energy ${ }^{7,8} . B$. myrrha plant is a spiny glabrous small trees frequently attain a height of about four to ten meters. Branches of the tree are often with thorny tips and knotted. Bark of the tree is usually lustrous silvery white or agleam bluish grey in color on its outer surface while with greenish underbark. The trees transude scarcely odorous, glutinous matter that acquired a hard-translucent yellow gum-resin ${ }^{4-7}$.
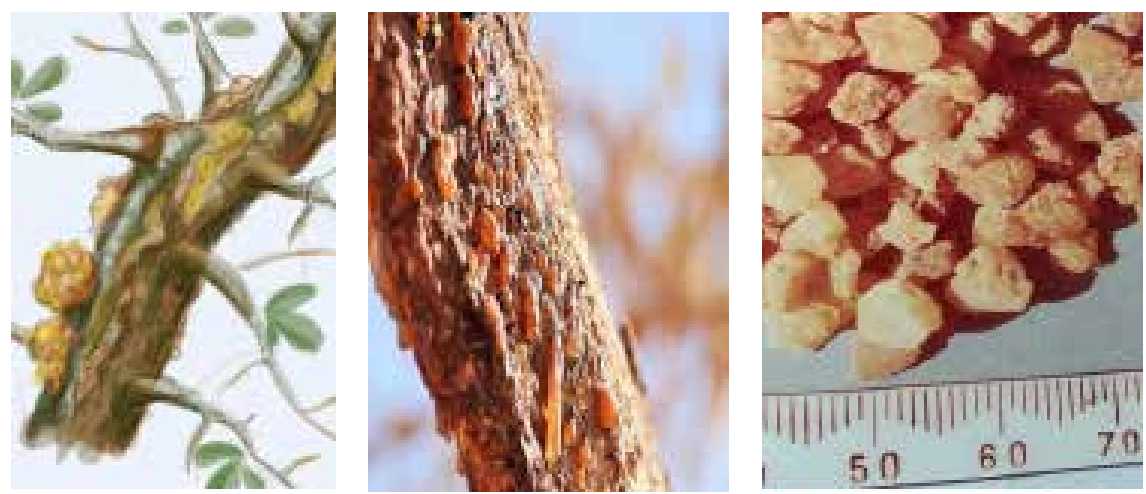

Figure 1. Balsamodendron myrrha Nees. tree with resin Oleo-Gum-resin Tears 
Although this plant was connatural to Peninsula, Somalia, Kenya, Ethiopia, Sudan, North East Africa, Abyssinia and Southern Arabia ${ }^{8}$, yet it had also been established in a dried hilly tract of Mansehra and Abbottabad (Hilly areas north of Pakistan), at an altitude of about 200 to 1000m with lime-stone containing soil and 200$250 \mathrm{~mm}$ of mean annual rainfall. The plant was also cultivated at some moist areas of Lahore regions (The capital of Punjab Province and central part of Pakistan) ${ }^{9}$.

Myrrh had been a significant natural plant product which was utilized in various applications including pharmacology, food, flavor, liqueur, beverage, cosmetics, perfumery and many others ${ }^{1-5,10}$. Myrrh had numerous indigenous assiduities in medicinal, hygienic and insecticidal domains ${ }^{1-5,10}$. In canonical medicines it had been utilized for revitalizing of numerous complaints from embalming to cancer, leprosy, bronchitis, diarrhoea, dysentery, typhoid fever, inflammatory complaints, hepatitis, contagious diseases, for wound healing, coughs, tumor and many others ${ }^{10}$. A myrrh resin has a mild disinfectant and local stimulant action on mucous membranes. Its tincture has also been applied in gargles and mouthwashes for mouth and pharynx ulcers ${ }^{1-4,6-8}$. It has also been employed to demolish a cacophonous odor, to promote granulations and to diminish the amount of released matter during nauseous ulcers ${ }^{1-4,6-8}$. Many research workers had investigated that both the myrrh oil and resin exhibited strong antiinflammatory, analgesic ${ }^{11}$, anti-microbial ${ }^{12-14}$, antibacterial ${ }^{15}$ and antifungal effects $^{16}$. It has also been implemented as dentifrice for cleaning and polishing the teeth $^{2,10}$. Internally myrrh was a carminative and flatus-relieving agent while in small doses it commonly encouraged appetite, produced warmth in stomach and provoked the flow of gastric juice ${ }^{2,10}$. Myrrh acted as a local anaesthetic on nerve cells ${ }^{14}$ and as an antiparasitic agent ${ }^{17}$. Myrrh had stimulating effects on female uterus and was utilized as an emmenagogue $\mathrm{e}^{1-3,8}$. In vitro anti diabetic and antiobesity activities of myrrh was also assessed ${ }^{18}$. It had also been probed that myrrh tinctures were effectively improved the glucose tolerance in both normal and diabetic rats ${ }^{18-20}$. Toxicity of solvent extracts of myrrh on goats ${ }^{22}$ and cytotoxic effects on human gynecologic cancer cells had been reported ${ }^{23}$. Myrrh had been employed from the distant ages as a component of incense and perfume, in the holy oil of Jew and the 'kyphi' of Egyptian for embalming and fumigations. Skin sensitizing potential of myrrh had also been reported ${ }^{24,25}$.

40 to $60 \%$ of partly water-soluble or a partly-ether soluble portion of myrrh oleo-gum-resin was designated as gum, about 40\% of an alcohol soluble portion was consisted of volatile oil and resins mixture ${ }^{28}$. Among the alcohol soluble portions, about 25 to $40 \%$ was belonging to a resin ${ }^{28}$. The volatile oils isolated from oleo-gum-resin of Balsamodendron species exhibited diverging percentages of mono, sesqui- and diterpenes in addition to some long chain hydro- 
carbons $^{1-4,7,8}$. Chemistry of myrrh oil was first investigated in 1906 by Lewinsohn ${ }^{27}$ and in 1907 by Friedrichs ${ }^{28}$. These research workers found $\alpha$-pinene, dipentene, limonene, \pm limonene. Later on these workers abstracted a number of compounds from B. myrrha oleo-resin, like -cumin aldehyde, cinnamic aldehyde, eugenol, m-cresol, isolinalyl acetate, 3-epilupenyl acetate, lupeone, 3 -epi- $\alpha$-amirin, $\alpha$-amirone, acetyl- $\beta$-eudesmol, cadinene, a sesquiterpene lactone, a bicyclic sesquiterpene (with $\mathrm{C}_{15} \mathrm{H}_{24}$ ), heerabolene (a tricyclic sesquiterpene), formic acid, acetic acid, myrrholic acid (with $\mathrm{C}_{16} \mathrm{H}_{21} \mathrm{O}_{3} . \mathrm{COOH}$ ) and palmitic $\operatorname{acid}^{27,28}$. Other groups of research workers depicted following phytochemical compounds in myrrh essential oil. -curzerene ${ }^{30-32}$, furanoeudesma-1,3-diene, 10(15)-furano-dien-6-one ${ }^{33,34}$, lindestrene ${ }^{35-37}$, curzerenone ${ }^{38,39}$, furanodien-6-one, dihydropyro-curzerenone, 3-methoxy-10(15)-dihydrofurano-dien-6-one, 3-meth-oxyfuranoguaia-9-en-8-one, 2-methoxy-4,5-dihydrofuranodien-6-one, 3-methoxy-10-methylene-furanogerma-cra-1-en-6-one ${ }^{38,39}$ and different aromatic sesqui-terpenes ${ }^{40,41}$. Ahmad etal (2006) ${ }^{42}$ recognized six compounds named as myrracadinol-A (cadina-3-en-15-ol); myrracalameneA (7,8-seco-2,5-dihydr-oxy-12-acetoxycalam-8-ene); myrracala-mene-B (7,8-seco-2,3,5-hydroxy-12-acetoxy- calame-8-ene); myrracadinol-B (7,8-secocadin-3,8-diene-2b,12-diol); myrracalamene-C (7,8-seco-12-hydroxy-calam8-ene) and myrracadinol-C (7,8-secocadin-3,7-dien-5a,10a-diol). On the other hands, Shuaib etal. (2014) ${ }^{43}$ isolated three tetracyclic triterpenoids named myrrhalanostenyl acetate (lanost-5,9(11),20(21), (Z)-23,25-pentaene-3 $\beta$-yl ace-

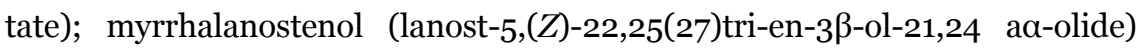
and myrrhalanostenoic acid (lanost-5-en-3a-ol-21,24a-olide-26-oic acid), along with $\mathrm{n}$-heptadecanyl capriate; $\mathrm{n}$-dodecanyl myristate and n-henetriacosanyl laurate aliphatic esters ${ }^{43} \cdot \gamma$-elemene and $Z$ - $\gamma$-bisabolene were also separated as major constituents from $B$. myrrha oleo-gum-resins ${ }^{44}$. Hosseinkhani etal ${ }^{45}$ found that although six unlike samples of myrrh oleoresin had different yields of their essential oils, yet all the samples revealed furanoeudesma-1,3diene, curzerene and lindestrene as their main constituents. Alcohol insoluble matter of myrrh gum mostly contained protein and carbohydrates. D-galactose, L-arabinose, D-glucuronic acid and 4-methyl-D-glucuronic acid as main carbohydrates were detected ${ }^{46}$. Branched polysaccharide of myrrh gum on hydrolysis furnished high yield of a mixture of sugars and acidic oligosaccharides. Acidic oligosaccharides were a admixture of two aldobiuronic acids, identified as 6-O-(4-O-methyl- $\beta$-D-glucuro-nosyl)-D-galactose and 4-O-(4-O-methyl- $\alpha$-Dglucuronosyl)-D-galac-tose $\mathrm{e}^{46,47}$. Among the protein portion of myrrh gum after hydrolysis, 15 amino acids were detected ${ }^{47}$ along with an oxidase enzyme whose activities were destroyed at $100^{\circ} \mathrm{C}^{47}$. 
B. myrrha Nees. plant was ascertained in dried hilly tract of Mansehra and Abbottabad (Hilly north part of Pakistan), at an altitude of about 200 to $1000 \mathrm{~m}$ with limestone soil and 200-250mm mean annual rainfall. A toxic reaction on hands of indigenous inhabitants was perceived during the assemblage of oleogum-resin from this plant. In spite of its copious usage in folk medicine and with its untoward reactions, no endeavor had been made to appraise its jejune/ hostile effects. In the present report, we delineated a comparative cytotoxic effect of some furanosesquiterpenes from this oleoresin on mature larvae (nauplii) of brine shrimps (Artemia salina), followed by fractionation to isolate and characterize its active compound/s, whose cytotoxic effect was further assessed by calculating their $\mathrm{LD}_{50^{\circ}}$.

\section{METHODOLOGY}

\section{General Experimental Procedures}

Unless otherwise stated, all the chemicals used were of analytical grade. Concentrations were executed under reduced pressure at bath temperatures not exceeding $50^{\circ} \mathrm{C}$. Melting points were determinated on Perfit apparatus with the help of open capillary tubing and were unrebuked. UV spectra were deliberated on Hitachi-270-30 spectrophotometer in $\mathrm{MeOH}$. IR spectra were secured as $\mathrm{KBr}$ disc or as thin film on $\mathrm{NaCl}$ discs on a Pye-Unicam SP-8-400 spectrophotometer. ${ }^{1} \mathrm{HNMR}$ spectra were procured in DMSO- $\mathrm{d}_{6}$ at $27 \mathrm{O} \mathrm{MHz}$ using TMS as an internal standard. ${ }^{13} \mathrm{C}$ NMR spectra were conducted on Bruker AM-30o $\mathrm{NMR}$, spectrometers with $75 \mathrm{MH}_{\mathrm{Z}}$, at $28^{\circ} \mathrm{C}$ and with $0.2-0.5 \mathrm{mM} / \mathrm{ml}$ concentrations of the samples, using 10mm tubes and TMS as an internal reference. EI and FD mass spectra were commemorated on a Varian MAT-312 double focusing mass spectrometer using the direct inlet method. FAB (positive), in glycerin, was acquitted on JEOL JMS-110 spectrometer. Column chromatography was executed on silica gel 60 (70-230 mesh ASTM No. 7734 of E. Merck, Damstadt, Germany), monitored its fractions by TLC. Both the analytical and preparatory TLC were performed with silica gel $\mathrm{PF}^{254+366}$ (from E. Merck Damstadt Germany) on $10 \times 20$ or $20 \times 20 \mathrm{~cm}$ glass plates. Analytical TLC with a depth of $0.25 \mathrm{~mm}$ thicknesses and preparatory TLC with $0.75 \mathrm{~mm}$ thick was utilized. The samples were applied as thin sports on analytical TLC and as narrow bands on preparatory TLC. Spots on chromatographs were visualized by a combination of UV fluorescence, exposing to 254/365 nm UV light, or with $\mathrm{I}_{2}$ vapors, or with vanillin $/ \mathrm{H}_{2} \mathrm{SO}_{4}$ reagent or with anisaldehyde/ $\mathrm{H}_{2} \mathrm{SO}_{4}$ reagent ${ }^{48,49}$. The separated bands on preparatory TLC were abraded off and eluted with methanol. 


\section{Plant materials}

Clean myrrh oleo-gum-resin tears (about $3 \mathrm{~kg}$ ) from B. myrrha Nees. were accumulated in August/September 2018 from the local people living around a hilly tract of Mansehra and Abbottabad at an altitude of nearly 900 meters. These tears were authenticated by Prof. Dr. Zaheer-ud-Khan, in charge herbarium, Department of Botany, Government College University, Lahore, Pakistan. A voucher specimen of the sample (No. P-cog.o157) was deposited in the Herbarium of Pharmacognosy Section, Faculty of Pharmacy, University of Central Punjab, Lahore for further reference. The myrrh tears were placed overnight in air at laboratory temperature and stored as such in amber colored glass bottles.

\section{Extraction and isolation}

$2.10 \mathrm{~kg}$ of the drug was dried in an oven at about $40^{\circ} \mathrm{C}$ for three days. It was finegranulated and extracted extensively with $96 \%$ ethanol in a Soxhlet extractor. Ethanol extract was concentrated under reduced pressure. The resulting resinous material was extracted repeatedly with hexane. The hexane extract was dried under reduced pressure to secure an oily viscous liquid (about 6.21g, yield $=0.3 \%)$. A dark brown, viscous mass ( 380 , yields $=18.90 \%)$ from hexane insoluble portion after drying was procured. $250 \mathrm{~g}$ of this extract was incorporated with a minimum amount of silica gel using methanol and after drying, it was pulverized into a fine powder. It was then adsorbed over silica gel column and chromatographed in light petroleum ether $\left(40-60^{\circ} \mathrm{C}\right)$. The column was eluted with petroleum ether, chloroform and methanol in order of increasing polarities. The eluents were accumulated after monitoring with TLC and fractions with similar compounds were pooled.

\section{Isolation of Compound-1}

Compound-1 was eluated from silica gel column with light petroleum ether with the initial 35 fractions (50ml each) of $100 \%$ pure petroleum ether and by preparatory TLC after utilization of petroleum ether/ $\mathrm{CHCl}_{3}$ (95:5). It prevailed a colorless amorphous powder which on recrystallization with hot $\mathrm{Me}_{2} \mathrm{CO} / \mathrm{MeOH}$ (75:25) acquired $321 \mathrm{mg}$ (with yield $=0.14 \%$ ) that appeared on TLC as a sin-

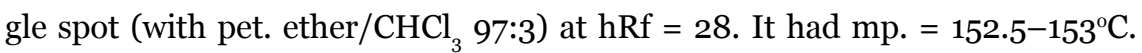
$[\alpha] \mathrm{D}^{28}+80^{\circ}\left(\mathrm{C} 0.06 \mathrm{CHCl}_{3}\right.$ ). FABMS, m/z (rel. intens. \%): $222\left[\mathrm{M}^{+}\right]\left(\mathrm{C}_{15} \mathrm{H}_{26} \mathrm{O}\right)$ (3.6), 154 (100). UV $\lambda_{\max }$ (MeOH): $204 \mathrm{~nm}(\log \mathrm{e}=3.4$ ). IR bands: 3442 (strong $\mathrm{OH}), 2960(\mathrm{C}-\mathrm{H}), 2848,1664$ (strong ketonic $\mathrm{C}=\mathrm{O}), 1468(\mathrm{C}=\mathrm{C}), 1344,112 \mathrm{Ocm}^{-}$ ${ }^{1} .{ }^{1} \mathrm{HNMR}\left(\mathrm{CDCl}_{3}\right), 8: 5.7 \mathrm{O}(1 \mathrm{H}, \mathrm{m}, \mathrm{H}-3), 3.35(1 \mathrm{H}, \mathrm{d}, J=7.3 \mathrm{~Hz}, \mathrm{H} 2-15 \mathrm{a}), 3.31$ (1H d, $J=7.5 \mathrm{~Hz}, \mathrm{H}-15 \mathrm{~b}$ ), 2.36 (2H, broad s, H2-2), 2.27 (6H, broad s, H2-5, H2-8, H2-9), 2.25 (2H, broad s, H-1, H-6), 2.15 (2H, broad s, H-7, H-1O), $1.7 \mathrm{O}$ 
(3H, broad s, Me-11), 1.16 (2H, m, H-12), 1.06 (3H, d, $J=6.5 \mathrm{~Hz}, \mathrm{Me}-13$ ), 1.08 $(3 \mathrm{H}, \mathrm{d}, J=6.7 \mathrm{~Hz}, \mathrm{Me}-14) .{ }^{13} \mathrm{CNMR}\left(\mathrm{CDCl}_{3}\right.$ ), $\delta: 51.17$ (C-1), 29.09 (C-2), 121.96 (C-3), 127.24 (C-4), 26.73 (C-5), 44.08 (C-6), 35.48 (C-7), 20.65 (C-8), 19.23 (C-9), 37.31 (C-10), 7.63 (C-11), 34.26 (C-12), 14.72 (C-13), 17.24 (C-14), 65.17 (C-15). The compound-1 was identified by comparing its spectral data with the reported data as myrracadinol-A ${ }^{42}$ (Figure 2.).

\section{Isolation of Compound-2}

Compound-2 was eluted from the column with 100\% light petroleum ether (with further 80 to 120 fractions of $50 \mathrm{ml}$ each) and by preparatory TLC after employing petroleum ether $/ \mathrm{CHCl}_{3}$ 90:10 as a solvent system. It came out as pale yellow precipitates which after re-crystallization from hot $\mathrm{Me}_{2} \mathrm{CO} / \mathrm{MeOH}$ (70:30) mixture rendered $385 \mathrm{mg}$ of pale-yellow amorphous powder (with $1.013 \%$ yield). It appeared on TLC at $\mathrm{hRf}=71$ (with pet. ether $/ \mathrm{CHCl}_{3}$ 80:20) as a single spot and

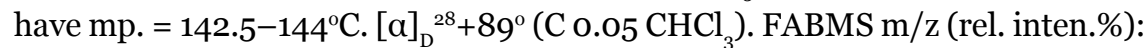
$238\left[\mathrm{M}^{+}\right]\left(\mathrm{C}_{15} \mathrm{H}_{26} \mathrm{O}_{2}\right)$ (6.8), 222 (12.2), 204 (23.8), 189 (19.9), 185 (16.5), 168 (22.9), 152 (21.6), 130 (24.8), 115 (37.3). UV $\lambda_{\text {max }}(\mathrm{MeOH}): 206 \mathrm{~nm}(\log \mathrm{e}=4.3)$. IR (KBr) bands: $3460(\mathrm{OH}), 1656$ (Ketonic $\mathrm{C}=\mathrm{O}), 1525,1475(\mathrm{C}=\mathrm{C}), 1398,1120$ $\mathrm{cm}^{-1} .{ }^{1} \mathrm{HNMR}\left(\mathrm{CDCl}_{3}\right)$ 8: 5.89 (1H, m, H-3), 5.52 (1H, m, H-9), 4.96 (1H, m, H28a), 4.71 (1H, d, $J=6.3 \mathrm{~Hz}, \mathrm{H} 2-8 \mathrm{~b}), 3.12(1 \mathrm{H}$, broad m, $J=8.3 \mathrm{~Hz}, \mathrm{H}-2 \mathrm{a}), 2.26$ (2H, m, H2-5), 1.91 (1H, m, H-10), 1.80 (1H, m, H-1), 1.73 (3H, broad s, Me-11), 1.53 (1H, m, H-6), 1.52 (2H, broad s, H2-7), 1.28 (6H, broad s, Me-13, Me-14), $0.82(3 \mathrm{H}, \mathrm{d}, J=6.2 \mathrm{~Hz}, \mathrm{Me}-15) .{ }^{13} \mathrm{C} \mathrm{NMR}\left(\mathrm{CDCl}_{3}\right) \delta: 47.55(\mathrm{C}-1), 70.46(\mathrm{C}-2)$, 127.26 (C-3), 141.38 (C-4), 26.26 (C-5), 40.23 (C-6), 16.80 (C-7), 111.26 (C-8), 115.40 (C-9), 35.26 (C-10), 7.46 (C-11), 69.38 (C-12), 20.30 (C-13), 15.34 (C-14), 28.72 (C-15). Compound-2 was identified by comparing its spectral data with the reported data as myrracadinol-B ${ }^{42}$ (Figure 2).

\section{Isolation of Compound-3}

Compound-3 was eluted from the column with light petrolum ether/ $\mathrm{CHCl}_{3}$ (90:10) from further 121 to 160 (each $50 \mathrm{ml}$ ) fractions and by preparatory TLC after using petroleum ether $/ \mathrm{CHCl}_{3}(85: 15)$ as a solvent system. It came out as oily grumous matter. It was kept at $6^{\circ} \mathrm{C}$ for overnight and re-crystallized from hot $\mathrm{MeOH}$. It furnished about 3.25g (1.3\% yield) of achromatic crystalline material. It appeared on TLC at $\mathrm{hRf}=16$ (with pet. ether $/ \mathrm{CHCl}_{3} 70: 30$ ) as a single spot, quenching under UV, gave a yellowish orange spot with anisaldehyde/ $\mathrm{H}_{2} \mathrm{SO}_{4}$ and have mp. $=65 \cdot 5^{-6} 7^{\circ} \mathrm{C}$. EIMS (rel. intens. \%): $\mathrm{m} / \mathrm{z} 216\left[\mathrm{M}^{+}\right]\left(\mathrm{C}_{15} \mathrm{H}_{20} \mathrm{O}\right.$ ) (2.5), 215 (30), 149 (9), 136 (14), 109 (10), 107 (12), 105 (12), 95 (12), 93 (16), 91 (16), 85 (71), 79 (12), 47 (30), 45 (22), 43 (100), 41 (20). UV $\lambda_{\max }(\mathrm{MeOH}): 256$ nm. IR (KBr) bands: 3466 (strong OH), 1660 (strong ketonic $\mathrm{C}=\mathrm{O}$ ), 1530, 1480 
(C=C), 1378, $1129 \mathrm{~cm}^{-1} .{ }^{1} \mathrm{HNMR}\left(\mathrm{CDCl}_{3}\right) 8: 7.07(1 \mathrm{H} \mathrm{s}, \mathrm{H}-12), 4.93(1 \mathrm{H}, \mathrm{dd}, J=$ $6.5,10.6 \mathrm{~Hz}, \mathrm{H}-1), 4.65$ (1H broad t, $J=7.1 \mathrm{H}-5), 3.56$ (1H d, $J=14.2, \mathrm{H}-9$ a), 3.45 ( $1 \mathrm{H} \mathrm{d}, J=14.1, \mathrm{H}-9 \beta$ ), 3.21 ( $2 \mathrm{H}$, broad d, $J=6.7, \mathrm{H}-2 \alpha, \mathrm{H}-2 \beta$ ), 2.78 ( $1 \mathrm{H} \mathrm{td}$,

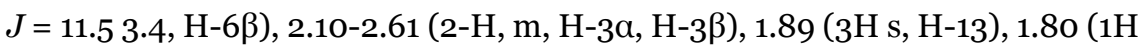
$\mathrm{dt}, J=7.111 .6, \mathrm{H}-6 \alpha), 1.62(3 \mathrm{H} \mathrm{s}, \mathrm{H}-14), 1.29(3 \mathrm{H} \mathrm{s}, \mathrm{H}-15) .{ }^{13} \mathrm{C} \mathrm{NMR}\left(\mathrm{CDCl}_{3}\right)$ 8: 130.0 (C-1), 24.35 (C-2), 26.79 (C-3), 128.71 (C-4), 127.4 (C-5), 39.42 (C-6), 118.82 (C-7), 149.63 (C-8), 40.81 (C-9), 134.31 (C-10), 121.80 (C-11), 135.9 (C12), 8.89 (C-13), 16.39 (C-14), 16.20 (C-15). Compound-3 was identified by comparing its spectral data with the reported data and with CAS ID $=19912-61-9$ as a germacrane sesquiterpenoid named as furanodiene ${ }^{51,54}$ (Figure 2).

\section{Isolation of Compound-4}

Compound-4 was eluted from the column with petroleum ether $/ \mathrm{CHCl}_{3}(70: 30)$ from further 161 to 190 (each $50 \mathrm{ml}$ ) fractions and by preparatory TLC after utilizing petroleum ether/ $\mathrm{CHCl}_{3}$ (80:15) as the band eluting solvent. This compound appeared to be light yellowish viscous liquid with $102 \mathrm{mg}$ quantity (0.041\% yield). It was homogenous on analytical TLC, as a single spot with hRf $=65$ (with pet. ether $/ \mathrm{CHCl}_{3} / \mathrm{MeOH}$ 80:3:1). It gave light blue colored spots with vanillin/ $\mathrm{H}_{2} \mathrm{SO}_{4}$. HRMS: $\mathrm{m} / \mathrm{z}$ 274.1561 [M]+ (calcd. for $\mathrm{C}_{17} \mathrm{H}_{22} \mathrm{O}_{3}$, 274.1568). EIMS (rel. intens. \%): m/z $274\left[\mathrm{M}^{+}\right]\left(\mathrm{C}_{17} \mathrm{H}_{22} \mathrm{O}_{3}\right)$ (23), 232 (20), 214 (35), 199 (24), 177 (14), 159 (12), 149 (21), 146 (42), 135 (15), 123 (17), 109 (13), 108 (100), 107 (16), 105 (14), 95 (13), 93 (19), 91 (25), 85 (79), 79 (13), 47 (32), 45 (23), 43 (45), 41 (22). UV $\lambda_{\max }(\mathrm{MeOH}): 252 \mathrm{~nm}$. IR (thin film) bands: 2930 (strong OH), 2870, 1730 (strong ketonic $\mathrm{C}=\mathrm{O}$ ), 1600, 1530 (strong), 1450 (C=C), 1435, 1375, 1240, 1100, 1020, 960, 850 and $76 \mathrm{ocm}^{-1} .{ }^{1} \mathrm{HNMR}\left(\mathrm{CDCl}_{3}\right) \delta: 7.05(1 \mathrm{H}, \mathrm{s} \mathrm{H}-12)$, $5.43(1 \mathrm{H}$, broad m, H-9), $5.05(1 \mathrm{H} \mathrm{t}), 4.98(1 \mathrm{H}, \mathrm{d}, \mathrm{H}-2), 3.49(2 \mathrm{H} \mathrm{s}), 3.39(3 \mathrm{H} \mathrm{s}$, $\mathrm{H}-2), 3.02$ (2H, d, $J=8 \mathrm{~Hz}, \mathrm{H}-5), 2.06$ (3H s), 1.92 (3H, d, $J=4 \mathrm{~Hz}, \mathrm{H}-10), 1.66$ $(3 \mathrm{H} \mathrm{s}), 1.40(3 \mathrm{H} \mathrm{s})$. Compound- 4 was identified by comparing its spectral data with those reported in the literature as 2-acetoxyfuranodiene ${ }^{54,55,57}$ (Figure 2).

\section{Isolation of Compound-5}

Compound- 5 was eluted from the column with petroleum ether/ $\mathrm{CHCl}_{3}$ (50:50) from further 191 to 240 fractions ( $50 \mathrm{ml}$ each) and by preparatory TLC after using pet. ether/ $\mathrm{CHCl}_{3}$ (70:30) as a band eluting solvent. This compound appeared to be colorless viscous liquid and was homogenous on analytical TLC as a single spot with $\mathrm{hRf}=0.75$ (in pet. ether/ $\mathrm{CHCl}_{3} / \mathrm{MeOH}$ 90:10:5). It afforded an intense violet colored spot with vanillin/ $\mathrm{H}_{2} \mathrm{SO}_{4}$. HRMS: $\mathrm{m} / \mathrm{z} 232.1542[\mathrm{M}]+$ (calcd. for $\left.\mathrm{C}_{15} \mathrm{H}_{20} \mathrm{O}_{2}, 232.1562\right)$. EIMS (rel. intens. \%): m/z $232\left[\mathrm{M}^{+}\right]\left(\mathrm{C}_{15} \mathrm{H}_{20} \mathrm{O}_{2}\right)$ (59), 204 (37), 189 (25), 176 (30), 175 (100), 162 (26), 161 (74), 150 (19), 149 (26), 147 (15), 137 (22), 133 (15), 123 (16), 122 (25), 121 (50), 119 (28), 109 (30), 
107 (31), 105 (42), 95 (41), 94 (17), 93 (44), 91 (33), 80 (48), 79 (30), 77 (19), 71 (32), 67 (30), 65 (9), 56 (41), 53 (20), 41 (50). UV $\lambda_{\max }(\mathrm{MeOH}): 234,280 \mathrm{~nm}$. IR (thin film) bands: 2938 (strong OH), 2870, 1700 (strong ketonic $\mathrm{C}=\mathrm{O}$ ), 1670, 1520, 1450 (strong $\mathrm{C}=\mathrm{C}$ ), 1370, 1230, 1104, 1090, 1030, 1018, 900, 895, 760 and $737 \mathrm{~cm}^{-1} .{ }^{1} \mathrm{HNMR}\left(\mathrm{CDCl}_{3}\right)$ 8: 7.09 (broad d, H-11), 6.91 (1H, broad s, H-12), 5.75 (broad s, H-5), 5.34 (1H, broad t, $J=9 \mathrm{~Hz}, \mathrm{H}-9$ ), 5.12 (1H broad dd, 6.5, $J=4.0$ $\mathrm{Hz} \mathrm{H-1)}, 3.67$ (broad s, H-9), 3.30 (2H m), 3.01 (d, $J=1.0 \mathrm{~Hz}, \mathrm{H}-13), 2.80(2 \mathrm{H}$, $\mathrm{m}$, a multiplet centered around $\delta 2.31), 2.46(\mathrm{td}, 11.2, J=3.7 \mathrm{~Hz}), 2.30(2 \mathrm{H} \mathrm{m})$, 2.17 (dt, 11.6, $J=3.4 \mathrm{~Hz}, \mathrm{H}-2$ ), 2.05(broad s, H-14), 1.92 (3H d, $J=4 \mathrm{Mz}$ ), 1.87 (dt 10.8, $J=4.0, \mathrm{H}-3$ ), 1.62 (3H broad s, H-2), 1.40 (broad s, H-15), $0.97(3 \mathrm{H}$, $\mathrm{d}, J=7 \mathrm{~Hz}, \mathrm{H}-5) .{ }^{13} \mathrm{C}$ NMR $\left(\mathrm{CDCl}_{3}\right)$ 8: 129.7 (C-1), 25.6 (C-2), 41.5 (C-3), 145.3 (C-4), 131.6 (C-5), 187.2 (C-6), 122.3 (C-7), 157.2 (C-8), 40.0 (C-9), 136.1 (C-10), 125.2 (C-11), 139.4 (C-12), 10.2 (C-13), 17.8 (C-14), 17.3 (C-15). Compound-5 was identified by comparing its spectral data with the reported data as furanodiene-6-one ${ }^{58}$ (Figure 2).

\section{Isolation of Compound-6}

Compound-6 was eluted from the column with $\mathrm{CHCl}_{3}: \mathrm{MeOH}$ (90:10) from further 241 to 352 (each $50 \mathrm{ml}$ ) fractions and by preparatory TLC after eleuting the bands with pet. ether $/ \mathrm{CHCl}_{3}$ (65:35). This compound came out as white amorphous powder, re-crystallized from hot $\mathrm{Me}_{2} \mathrm{CO} / \mathrm{MeOH}$ (80:20) which afforded $380 \mathrm{mg}$ amount (about $0.152 \%$ yield) and was homogenous on analytical TLC. It came out as a single spot with $\mathrm{hRf}=65$ (in pet. ether $/ \mathrm{CHCl}_{3} / \mathrm{MeOH}$ 90:20:7). It had a strong quenching under UV, gave a pink spot with vanillin $/ \mathrm{H}_{2} \mathrm{SO}_{4}$ and with mp. 59-61 ${ }^{\circ} \mathrm{C}$. EIMS (rel. intens. \%) m/z: $246\left[\mathrm{M}^{+}\right]\left(\mathrm{C}_{16} \mathrm{H}_{22} \mathrm{O}_{2}\right)(25), 215(15)$, 176(20), 166(20), 159(30), 149(15), 147(27), 138(15), 123(30), 119(15), 107(18), 91 (42), 85(43), 77(40), 55(42), 45(100), 40(15), 39(20). UV $\lambda_{\max }(\mathrm{MeOH})$ : 210nm. IR (thin film) bands: 2970(strong OH), 2930, 2910, 2860, 2840, 1670 (strong ketonic $\mathrm{C}=\mathrm{O}$ ), $1600,1560,146 \mathrm{o}(\mathrm{C}=\mathrm{C}), 1420,1380,1180,1160$, 1120, 1090, 960, 810 and $760 \mathrm{~cm}^{-1} .{ }^{1} \mathrm{HNMR}\left(\mathrm{CDCl}_{3}\right)$ 8: 7.04 (1H, broad s, $\left.\mathrm{H}-12\right)$, $5.03(2 \mathrm{H}, \mathrm{m}, \mathrm{H}-9), 4.11(1 \mathrm{H} \mathrm{m}), 3.62(2 \mathrm{H}$ broad s), $3.45(3 \mathrm{H} \mathrm{s}), 3.10$ (2H, d, $J=$ $7.5 \mathrm{~Hz}), 2.5 \mathrm{O}(2 \mathrm{H} \mathrm{m}), 1.91(3 \mathrm{H} \mathrm{d}, J=3 \mathrm{~Hz}, \mathrm{H}-2), 1.61(3 \mathrm{H}$, broad s, $\mathrm{H}-5), 1.0(3 \mathrm{H}$ broad s). The compound 6 was identified by comparing its spectral data with the reported data as 2-methoxyfuranodiene of furanogermacrane ${ }^{59}$ (Figure 2). 

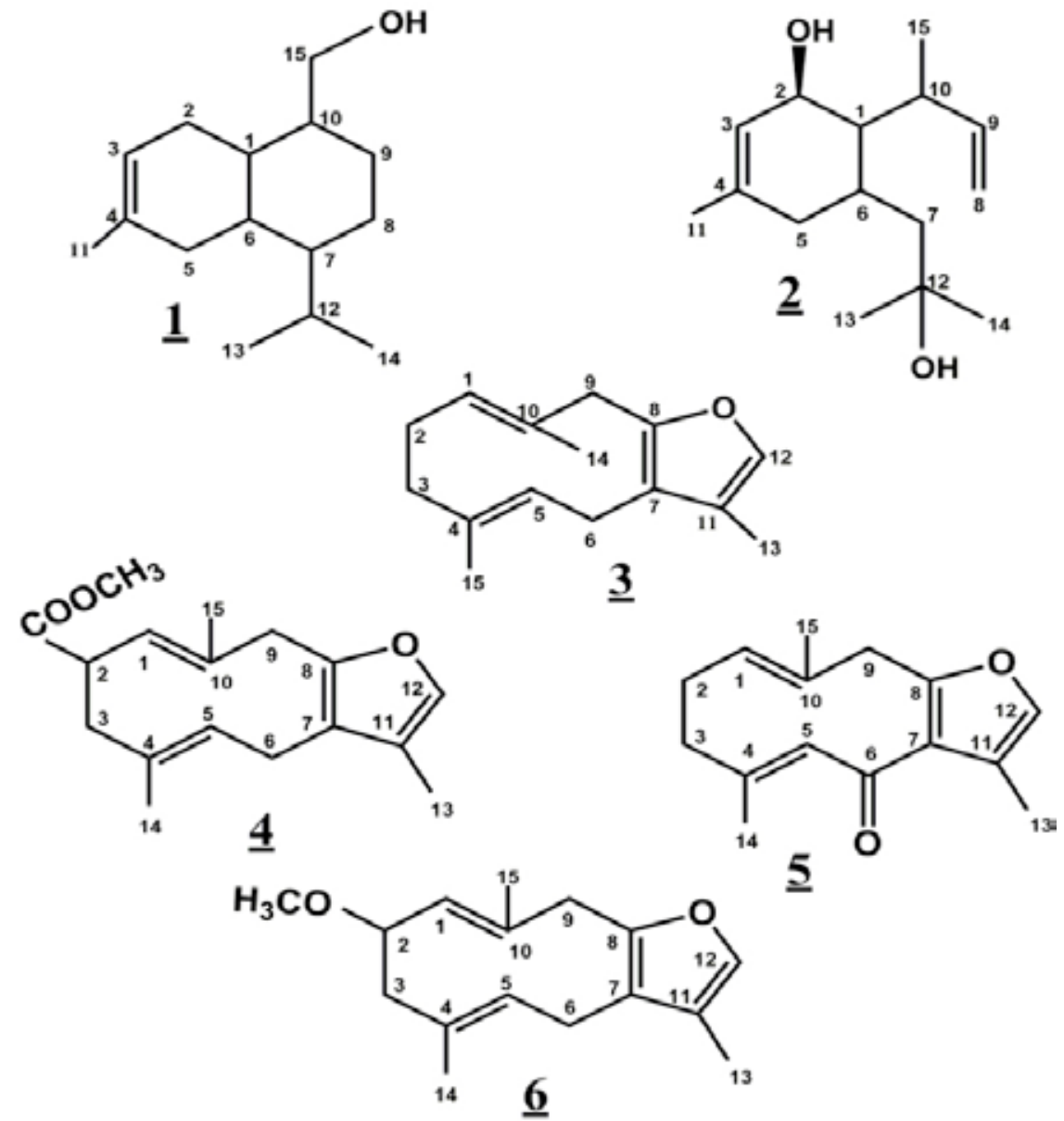

Figure 2. Furanosesquiterpenes isolated from Balsamodendron myrrha oleo-gum-resin

\section{Brine Shrimp (Artemia salina Leach) Lethality Bioassay}

This assay was embraced from the method already portrayed in literature ${ }^{61-65}$. The eggs of brine shrimps (Artemia salina Leach) were redeemed from an indigenous fish shop. A brine shrimp container was filled with artificial sea water (about 3.7\%) ${ }^{63,65}$. The seawater was merged with salts like $\mathrm{MgCl}_{2} \cdot 6 \mathrm{H}_{2} \mathrm{O}, \mathrm{Na}_{2} \mathrm{SO}_{4}$, $\mathrm{CaCl}_{2} \cdot 2 \mathrm{H}_{2} \mathrm{O}$ or $\mathrm{CaCl}_{2} \cdot 6 \mathrm{H}_{2} \mathrm{O}^{62,63}$. Sea salt and yeast suspension (in the ratio of $3 \mathrm{mg}$ dried yeast for each $5 \mathrm{ml}$ of sea water), were also purchased from the local fish store. Syringes of $5 \mathrm{ml}, 1 \mathrm{ml}, 500 \mu l$ 's, $100 \mu \mathrm{l}, 50 \mu \mathrm{l}$ and $10 \mu \mathrm{l}$ ability and 2-dram vials (9 per sample and $3+3$ for each control) were also ransomed from the domestic market. Sea salt solution was produced by disbanding $38 \mathrm{~g}$ sea salts in $1000 \mathrm{ml}$ of distilled water and filtered. This solution was taken in a small 
fictile tubful that was divided by a uniformed muddle partition with consistent holes in it. The eggs were besprent on one side of the muddled partition which was then embraced with a carbon paper. Other half of the tubful was illuminated with an electric lamp to draw in the hatched shrimps. The solution in the tubful was incessantly provided with a regular air flow with an average pressure and proper light conditions which were necessary for hatching litigates ${ }^{63,64}$. After 48 hours, the shrimps hatched and matured as nauplii. The mature nauplii was then utilized further for the experiment. $20 \mathrm{mg}$ of each of the compound was taken in small vial and dissolved in $2 \mathrm{ml}$ of methanol to swear out as a stock solution. From the stock solution, $500 \mu \mathrm{l}, 400 \mu \mathrm{l}, 300 \mu \mathrm{l}, 200 \mu \mathrm{l}, 100 \mu \mathrm{l}$, $50 \mu \mathrm{l}, 40 \mu \mathrm{l}, 30 \mu \mathrm{l}, 20 \mu \mathrm{l}, 10 \mu \mathrm{l}$ and $5 \mu \mathrm{l}$ (corresponding to the 1000, 800, 600, $400,200,100,80,60,40,20$ and $10 \mu$ r respectively) were channelized to the vials with three replicates of each engrossment of the isolated compound. The vials were then placed in an open area for 24 hours for a complete removal of methanol after vaporization. $2 \mathrm{ml}$ of sea salt solution was then added in each vial. 10 brine shrimp's larvae were transferred to each vial (30 brine shrimps per dilution) with the help of a long-tipped dropper. Total volume of the liquid in each vial was adjusted to $5 \mathrm{ml}$ with sea salt solution. After 24 hours, the facetious or nonresonant brine shrimps were counted for all the concentrations of the isolated compounds ${ }^{61-64}$. Colchicine ${ }^{64,65}$ in the same concentrations was employed as a positive control. Total number of devastated brine shrimp's larvae per dilution of each compound was tabulated. $\mathrm{LC}_{50}$ (lethal concentration in $50 \%$ individuals) was computed by probit analysis ${ }^{66}$, using a computer program ${ }^{67}$. The number of exterminated brine shrimp's larvae due to the upshot produced by the six isolated compounds from B. myrrha oleo-gum-resin and also by colchicine, their $\mathrm{LC}_{50}$, has been outlined in Table-1.

\section{RESULTS AND DISCUSSION}

The indecorous outcomes due to B. myrrha oleo-gum-resin (myrrh oleo-gumresin) were conglomerated by the indigenous inhabitants living in the hilly areas of Mansehra and Abbottabad, at an altitude of about 200 to 100om. A toxic reaction on the hands was ascertained during the accumulation of myrrh. Skins of abaxial sides of hands and arms were often involved. It frequently developed erythematous inflammation, after prolong handling the fresh myrrh oleo-gumresin. The apparent toxic reaction induced by the oily material from fresh $B$. myrrha oleo-gum-resin was resolved after five or six days. This type of atrocious salacious reaction of the myrrh oleo-gum-resin on human skin incited us to carry out an investigation about the chemical nature of their hostile active compounds. 
Table 1. Cytotoxic effect of the compounds isolated from B. myrrha oleo-gum-resin on brine shrimps' larvae.

\begin{tabular}{|c|c|c|c|c|c|c|c|}
\hline \multirow{2}{*}{$\begin{array}{c}\text { Dose } \\
\text { levels } \\
(\mu \mathrm{g} / \mathrm{ml})\end{array}$} & \multicolumn{7}{|c|}{ Compounds } \\
\hline & Comp. 1 & Comp. 2 & Comp. 3 & Comp. 4 & Comp. 5 & Comp. 6 & Colci. \\
\hline 400 & $27^{*} / 30^{\dagger}$ & $22 / 30$ & $12 / 30$ & $10 / 30$ & $22 / 30$ & $21 / 30$ & $28 / 30$ \\
\hline 200 & $25 / 30$ & $20 / 30$ & $11 / 30$ & $8 / 30$ & $21 / 30$ & $20 / 30$ & $27 / 30$ \\
\hline 100 & $21 / 30$ & $19 / 30$ & $9 / 30$ & $6 / 30$ & $20 / 30$ & $18 / 30$ & $25 / 30$ \\
\hline 80 & $20 / 30$ & $18 / 30$ & $8 / 30$ & $5 / 30$ & $19 / 30$ & $17 / 30$ & $21 / 30$ \\
\hline 60 & $18 / 30$ & $16 / 30$ & $7 / 30$ & $2 / 30$ & $18 / 30$ & $15 / 30$ & $20 / 30$ \\
\hline 40 & $17 / 30$ & $13 / 30$ & $5 / 30$ & $1 / 30$ & $17 / 30$ & $14 / 30$ & $18 / 30$ \\
\hline 20 & $16 / 30$ & $12 / 30$ & $3 / 30$ & $0 / 30$ & $15 / 30$ & $12 / 30$ & $17 / 30$ \\
\hline 10 & $14 / 30$ & $11 / 30$ & $2 / 30$ & $0 / 30$ & $14 / 30$ & $10 / 30$ & $15 / 30$ \\
\hline 5.0 & $12 / 30$ & $10 / 30$ & $0 / 30$ & - & $9 / 30$ & $8 / 30$ & $13 / 30$ \\
\hline 2.5 & $10 / 30$ & $8 / 30$ & - & - & $7 / 30$ & $5 / 30$ & $11 / 30$ \\
\hline 1.25 & $8 / 30$ & $4 / 30$ & - & - & $5 / 30$ & $3 / 30$ & $4 / 30$ \\
\hline $\mathrm{LC}_{50}(\mu \mathrm{g})$ & 28.65 & 31.41 & 419.58 & 754.32 & 30.56 & 33.27 & 27.32 \\
\hline S.D. & 0.85 & 0.84 & 0.81 & 0.79 & 0.84 & 0.83 & 0.78 \\
\hline$x^{2}$ & 1.78 & 2.35 & 1.52 & 0.48 & 1.56 & 1.67 & 1.58 \\
\hline d. f. & 27 & 26 & 1.51 & 0.308 & 27 & 26 & 25 \\
\hline
\end{tabular}

Comp. $\mathbf{1}$ = myrracadinol A; Comp. $\mathbf{2}$ = myrracadinol B; Comp. $\mathbf{3}$ = furanodiene; Comp. $\mathbf{4}=$ 2-acetoxyfuranodiene;

Comp. $\mathbf{5}$ = furanodiene-6-one; Comp. $\mathbf{6}$ = 2-methoxyfuranodiene; Colci. = Colchicine

*=Number of brine shrimps killed after 24 hours;

$\dagger=$ Total number of brine shrimps used;

LC50 = Lethal concentration where $50 \%$ brine shrimps larvae were killed;

S.D.= Standard deviation; $x^{2}=$ Chi square; d.f.= degree of freedom.

During the preliminary cytotoxic assay, it was detected that the ethanolic extract of B. myrrha oleo-gum-resin was fatal to the brine shrimps (Artemia salina) larvae (nauplii). The ethanolic extract was further fractionated into hexane soluble nonpolar portion and hexane insoluble polar fraction which was chromatographed by column and preparative TLC to sequestrate their active cytotoxic constituent/s. Six cytotoxic compounds videlicet as compound-1 (myrracadinol-A); compound-2 (myrracadinol-B); compound-3 (furanodiene); compound-4 (2-acetoxy-furanodiene); compound-5 (furanodiene-6-one) and compound-6 (2-methoxy-furanodi- 
ene) were abstracted from the hexane insoluble portion of ethanol extract by column chromatography and were purified by preparative TLC and recrystallization. These compounds were identified as furanosesquiterpenes by comparative physical and spectral data of previously reported similar compounds (Figure 2). Previously many research workers had isolated and characterized similar furanosesquiterpenes from myrrh oleo-gum-resin and from other oils and resins si-45,50-60. $^{\text {. }}$

Many research workers had taken advantage of brine shrimp (the larvae i.e., nauplii of mature brine shrimps - Artemia salina), assay for assessing the cytotoxicity of crude solvent extracts, column fractions and phytochemical compounds isolated from various natural sources ${ }^{61-65}$. This assay was thus assisted to appraise the cytotoxic activity. It was therefore employed to expedite the bioactive directed column fractions and preparatory TLC bands that maneuver the bioactive phytochemical compounds from the natural products towards cytotoxicity. Bioactive furanosesquiterpenes from B. myrrha oleo-gum-resin (Figure 2) were manifested as lethality to the brine shrimp's larvae. It was believed that the difference between toxicity and efficacy of such compounds is only the dosage ${ }^{61,62,65}$. This assay often manouevre the column fractions from different solvent extracts of natural products towards worthful bioactive phytochemical compounds. Cytotoxic effects were frequently evinced by the research workers in ppm or in $\mu \mathrm{g}$ as $\mathrm{LC}_{50}$ values with $95 \%$ confident levels ${ }^{61,62,65}$. To compare the cytotoxic effect of furanosesquiterpenes the brine shrimp larvae's assay appeared to be an appropriate manner of quantifying the $\mathrm{LD}_{50}$ (Lethal dose in at least $50 \%$ individuals) at time, in which the destruction of such larvae was ascertained. Input data for a computer program consisted of the specific dose, total number of test animals' larvae used, and the number of test animals' larvae reacted (i.e., the number of dead larvae) for a particular dose. The computer program transmute the dose to the log dose and the proportion of test animals' larvae reacted to the probit of percentage response. It then reconciled with a probit regression line to the resulting points and computing the values of $\mathrm{LD}_{50}$ along with standard deviation and a value of $\chi^{2} 66,67$. The output consisted of a listing of $\mathrm{LD}_{50}$, standard deviation and a value of $\chi^{2}$. The aim of the $\chi^{2}$ test was to find out whether the assay, after transformation was sufficiently constituted by a probit regression line. If the $\chi^{2}$ test pointed out, a deviation of transformed results from linear shape, these could not be assigned to a random biological variation (i.e. if $\chi^{2}$ value is not significant at $p>0.05$ ), then the results secured by probit analysis would not be legitimate ${ }^{66}$. The results pointed out that the six furanosesquiterpenes isolated from B. myrrha oleo-gum-resin demonstrated a cytotoxic effect against the brine shrimps' larvae when compared with the known cytotoxic compound colchicine ${ }^{64,65}$, utilized in the same assiduity (Table 1). 
The results further indicated that among the isolated compounds, the compound-1 (myrracadinol A), compound-2 (myrracadinol B), compound -5 (furanodiene-6-one) and compound-6 (2-methoxyfuranodiene) came out to be the most active compounds (with least $\mathrm{LC}_{50}=28.65,31.41,30.56$ and 33.27) when compared with other two like compound-3 (furanodiene) and compound-4 (2-acetoxy-furanodiene) (with $\mathrm{LC}_{50}=419.58$ and 754.32) and also with the positive controlled colchicine (with $\mathrm{LC}_{50}=27.32$ ) (Table 1). Out of the four most active compounds, compound-1 (myrracadinol A) appeared to possess the highest cytotoxic activity with the least $\mathrm{LC}_{50}$. Its cytotoxic potentiality seemed to be a terminus to the colchicine (Table 1). Furthermore, the results also pointed out that two of the furanosesquiterpenes, i.e., the compounds-3 (furanodiene) and -4 (2-acetoxyfuranodiene) exhibited lesser cytotoxic effect (Least $\mathrm{LD}_{50}$ ) against the brine shrimps' larvae than other four furanosesquiterpenes and also lesser than colchicine (Table 1).

The toxic response on brine shrimps' larvae, caused by myrracadinol A, myrracadinol B, furanodiene-6-one and 2-methoxyfuranodiene from B. myrrha oleogum-resin was probably due to their rapid acculturation through the larvae's skin and quickly bio-available to the living tissues. These compounds perhaps barricaded the respiratory or nervous centers and caused speedy tissue deterioration in the larvae, leading to their death. The comparatively less toxic reactions of furanodiene and 2-acetoxyfuranodiene were perhaps due to their direct actions, at some of the receptor sites in the larvae.

We concluded that the hexane insoluble portion of EtOH extract of B. myrrha oleoresin restrained closely related cytotoxic furanosesquiterpenes which could be hostile, not only to the brine shrimps' larvae but also insalubrious to the bodies of higher animals and human beings.

Further work is the requisite to amplify this dimension through the preparation of these compound's derivatives which would possibly direct to the structureactivity relationship of such an important cytotoxic molecules, not only in vivo in the bodies of the lower and higher animals as well as in human being's torso but also in vitro. These cytotoxic molecules and their derivatives might also be an important against carcinogenic tissues both in animal and human's bodies, which could further be ascertained in conformity with the criterion procedures of $\mathrm{WHO}^{68}$. Further work is also contrived to find some cytotoxic inhibitor/s from our natural sources which could subjugate the hostile activeness of such phytochemical compounds from B. myrrha oleoresin and related species of the family Burseraceae. 


\section{ACKNOWLEDGEMENTS}

The author and co-author are thankful to the staff of Applied Chemistry Section, PCSIR Laboratories, Lahore, Pakistan for procuring EIMS, FDMS, FABMS, ${ }^{1} \mathrm{H}$ NMR and ${ }^{13} \mathrm{CNMR}$ spectra. Another thanks are presented to the staff of Department of Botany, Government College University Lahore (GCU) for their help. Special thanks to Prof. Dr. Zaheer-ud-Khan, in-charge herbarium, Department of Botany, GCU. Lahore, Pakistan for authenticating the materials. 


\section{REFERENCES}

1. Evans, W. C. Volatile oils and resins. In Trease and Evans Pharmacognosy, 15th ed.; W. B. Saunders, New York. 2002; pp 253-288.

2. Usmanghani, K.; Saeed, A.; Alam, M. T. Commiphora myrrha (Nees) Engler. In Indusyunic medicine; Department of Pharmacognosy, Faculty of Pharmacy, University of Karachi, Karachi-75270, Pakistan 1997; pp 172,173.

3. Robbers, J. E.; Speedie, M. K.; Tyler, V. E. Resins and resin combinations. In Pharmacognosy and pharmacobiotechnology. William \& Wilkins, A Lea \& Febiger book, Philadelphia, 1996; pp 99-104.

4. Wallis, T. E. Resins, gum-resins, oleo-gum-resins. In Textbook of Pharmacognosy 2nd ed.; J \& A Churchill Ltd. London 1951; pp 450-481.

5. Hill, A. F. Gums and resins (Oleoresins) In Economic Botany $2^{\text {nd }}$ ed.; McGraw-Hill Book Company, New York 1952; pp. 162-166.

6. Colombini, M.P.; Modugno, F.; Silvano, F.; Onor, M. Characterization of the balm of an Egyptian mummy from the Seventh Century BC. St. Conser. 2ooo, 45, 19-29.

7. Hanuš, L. O.; Řezanka, T.; Dembitsky, V. M.; Moussaieff, A. Myrrh-Commiphora Chemistry. Biomed. Papers, 2005, 149, 3-28.

8. Dharmananda, S. Myrrh and frankincense. In Portland, OR, Institute for traditional medicine, 2003; pp 1-7.

9. Parker, R. N. Commiphora Jacq. (Balsamodendron, Kunth.) of Burseraceae. In A forest flora for the Punjab with Hazara and Delhi. The superintendent, Government Printing Punjab, Lahore. 1918; pp 69-71.

10. Lemenih, M.; Teketay, D. Frankincense and myrrh resources of Ethiopia: II. Medicinal and industrial uses. Ethiop. J. Sci. 2003, 26, 161-172.

11. Su, S.; Wang, T.; Duan, J. A.; Zhou, W.; Hua, Y. Q.; Tang, Y. P.; Yu, L.; Qian, D. W. Antiinflammatory and analgesic activity of different extracts of Commiphora myrrha. J. Ethnopharmacol. 2011, 134, 251-258.

12. Rapper, S. De.; Vuuren, S. F. V.; Kamatou, G. P. P.; Viljoen, A. M.; Dagne, E. The additive and synergistic antimicrobial effects of select frankincense and myrrh oils - a combination from the pharaonic pharmacopoeia. Lett. App. Microbio. 2012, 54, 352-358.

13. Alotaibi, G.; Irfan, U. M.; Ali, S. An in-vitro study to test antimicrobial effects of Commiphora myrrha in comparison to biocides. Eup. J. Pharmaceu. Med. Res. 2017, 4, 449-453.

14. Dolara, P.; Corte, B.; Ghelardini, C.; Pugliese1, A. M.; Cerbai, E.; Menichetti, S.; Nostro, A. L. Local anaesthetic, antibacterial and antifungal properties of sesquiterpenes from myrrh. Planta Med. 2000, 66, 356-358.

15. Shaik, J.; Vishakha, K.; Ramyasree, D. Evaluation of antibacterial activity of Commiphora myrrha against antibiotic resistant clinical pathogens. Ind. J. Pharm. Biol. Res. (IJPBR), 2015, 3, 7-11.

16. Al-Sabri, A. E.; Moslem, M. A.; Hadi, S.; Yassin, M. A.; Ameen, F. Antifungal activity of Commiphora myrrha L. against some air fungi. J. Pure App. Microbio. 2014, 8, 3951-3955.

17. Rashad, A.; Ghani, A.; Loutfy, N.; Hassan, A. Myrrh and trematodoses in Egypt. An overview of safety, efficacy and effectiveness profiles. Parasito. Intern. 2009, 58, 210-214.

18. Hady, H. A.; Wakil, E. A. E.; Morsi, E. A. Characterization of ethyl acetate and methanol extracts of Commiphora myrrha and evaluating in vitro anti-diabetic and anti-obesity activi- 
ties. J. Appl. Pharmaceu. Sci. 2019, 9, 38-44.

19. Awadi, F. M. A.; Gumaa, K. A. Studies on the activity of individual plants of an antidiabetic plant mixture. Acta diabetologia latina 1987, 24, 37-41.

20. Nada. S. A.; Bashandy, S. A. E.; Negm, S. A. Evaluation of the hypoglycemic activity of a traditional herbal preparation in male diabetic rats. Fitoterapia 1997, 68, 240-244.

21. Ubillas, R. P.; Mende, C. D.; Jolad, S. D.; Luo, J.; King, S. R.; Carlso, T. J.; Fort, D. M. Antihyperglycemic furanosesquiterpenes from Commiphora myrrha. Planta Med. 1999, 65, 778-779.

22. Omer, S. A.; Adam, S. E. Toxicity of Commiphora myrrha to goats. Vet. Hum. Toxicol. 1999, 41, 299-230.

23. Su, S.; Wang, T.; Chen, T.; Duan, J. A. O.; Yu, L.; Tang, Y. Cytotoxicity activity of extracts and compounds from Commiphora myrrha resin against human gynecologic cancer cells. $J$. Med. Pl. Res. 2011, 5, 1382-1389.

24. Zhou, Q.; Liu, Y.; Tang, Y.; Shokoohinia, Y.; Chittiboyina, A. G.; Wang, M.; Avonto, C. Article identification of potential skin sensitizers in myrrh. Cosmetics 2019, 6(3), 47.

25. Gallo, R.; Rivara, G.; Cattarini, G.; Cozzani, E.; Guarrera, M. Allergic contact dermatitis from myrrh. Contact Dermat. 1999, 41, 230-231.

26. El-Ashry, E. S.; Rashed, N.; Salama, O. M.; Saleh, A. Components, therapeutic value and uses of myrrh. Pharmazie 2003, 58, 163-168.

27. Lewinsohn, K. 'About myrrh oil'. Pharmacy Archives, 1906, 244(6-7), 412-435. Wiley online library, New York.

28. Friedrichs, V. 'Myrrh oil' Archives of Pharmacy, 1907, 245, 432.

29. Ishii, H.; Tozyo, T.; Nakamura, M.; Takeda, K. Components of the root of lindera strychnifolia Vill-XIII. Structure of isogermafurene and liner-oxide. Tetrahedron 1968, 24, 625-631.

30. Hikino, H.; Agatsuma, K.; Takemoto, T. Structure of curzerenone, epicurzerenone and isofuranogermacrene (curzerene). Tetrahedron Lett. 1968, 9, 2855-2858.

31. Hikino, H.; Agatsuma, K.; Konno, C.; Takemoto, T. Sesquiterpenoids. 35. Structure of furanodiene and isofuranogermacrene (curzerene) Chem Pharm Bull 1970, 18, 752-755.

32. Malingre, T. M. Curcuma xanthorrhiza, Temoe Lawak, a plant with cholagog activity. Pharm Week bl 1975, 110, 601-610.

33. Hikino, H.; Agatsuma, K.; Takemoto, T. Furanodiene, a precursor of furan containing sesquiterpenoids. Tetrahedron Lett. 1968, 9, 931-933.

34. Hikino, H.; Konno, C.; Agatsuma, K.; Takemoto, T.; Horibe, I.; Tori, K.; Ueyama, M.; Takeda, K. Sesquiterpenoids 47. Structure, configuration, conformation and thermal rearrangement of furanodienone, isofuranodienone, curzerenone, epicurzerenone and pyrocurzerenone, sesquiterpenoids of Curcuma zedoaria. J. Chem. So. Perk. T. 1975, 1, 478-484.

35. Hikino, H.; Hikino, Y.; Yosioka, I. Structure and autoxidation of atractylon. Chem. Pharm. Bull. 1962, 10, 641-642.

36. Takeda, K.; Minato, H.; Miyawaki, M.; Ishikawa, M. Components of root of Lindera strychnifolia VILL 9. Structures of lindestrene and linderene acetate. Tetrahedron 1964, 20, 26552663.

37. Takeda, K. I.; Ishii, H.; Tozyo, T.; Minato, H. Components of root of Lindera strychnifolia VILL 16. Isolation of lindenene showing a new fundamental sesquiterpene skeleton and its correlation with linderene. J. Chem. Soc. C. 1969, 14, 1920-1921. 
38. Fukushima, S.; Kuroyana, M.; Ueno, A.; Akahori, Y.; Saiki, Y. Structure of curzerenone, a new sesquiterpene from Curcuma zedoaria. Yakugaku Zasshi 1970, 9o, 863-869.

39. Uematsu, S.; Akahori, Y.; Fukushima, S.; Saiki, Y.; Ueno, A.; Kuroyana, M. A nuclear magnetic resonance study of curzerenone. Chem. Pharm. Bull. 1970, 18, 1118-1123.

40. Baser, K. H. C.; Demirci, B.; Dekebo, A.; Dagne, E. Essential oils of some Boswellia spp., Myrrh and Opopanax. Flavour Fragrance J. 2oo3, 18, 153-156.

41. Zhu, N.; Sheng, S.; Sang, S.; Rosen, R. T.; Ho, C. T. Isolation and characterization of several aromatic sesquiterpenes from Commiphora myrrha. Flavour Fragrance $J . \mathbf{2 0 0 3}, 18$, 282-285.

42. Ahmed, F.; Ali, M.; Singh, O. New compounds from Commiphora myrrha (Nees) Engl Pharmazie, 2006, 61, 728-731.

43. Shuaib, M.; Ali, M.; Naquvi, K. J. New lanostene-type triterpenes from the oleo-gum-resin of Commiphora myrrha (Nees) Engl. Int. J. Pharm. Pharm. Sci. 2014, 6, 372-375.

44. Ammar, N. M.; Hawary, S. S. E.; Mahdy, A. A.; Hussein, R. A.; Okino, T. Phytochemical study of the biologically active fractions of the oleo-gum-resins of Boswellia carteri and Commiphora myrrha. Adv. Env. Bio. 2013, 7, 2573-2583.

45. Hosseinkhani, A.; Ghavidel, F.; Mohagheghzadeh, A.; Zarshenas, M. M. Analysis of six populations of Commiphora myrrha (Nees) Engl. oleo-gum resin. Tre. Pharmaceu. Sci. 2017, $3,7-12$.

46. Jones, J. K. N.; Nunn, J. R. The constitution of gum myrrh. Part II. J. Chem. Soc. 1955 , 3001-3004.

47. Hough, L.; Jones, J. K. N.; Wadman, W. H. Some observations on the constitution of gum myrrh. J. Chem. Soc. 1952, 796-800.

48. Stahl, E. Thin layer chromatography. Springer-verlag, Berlin, New York 1969.

49. Wagner, H.; Bladt, S.; Zgainski, E. M. Plant Drug Analysis. Springer, Berlin 1984; p.299.

50. Brieskorn, C. H.; Noble, P. Three new furanogermacrenes from myrrh. Tetrahedron Lett. 1980, 21, 1511-1514.

51. Brieskorn, C. H.; Noble, P. Constituents of the essential oil of myrrh. Planta Med. 1982, 44, 87-90.

52. Brieskorn, C. H.; Noble, P. The terpenes of the essential oil of myrrh. In Aromatic plants Basic and applied aspects. Morgaris, N.; Koedam, A.; Vokou, D. (Eds.), Martinus Ni;hoff Publishers, The Hague Boston 1982.

53. Brieskorn, C. H.; Noble, P. Two furanoeudesmanes from the essential oil of myrrh. Phytochem. 1983, 22, 187-189.

54. Brieskorn, C. H.; Noble, P. Furanosesquiterpenes from the essential oil of myrrh. Phytochem. 1983, 22, 1207-1211.

55. Maradufu, A. Furanosesquiterpenoids of Commiphora erythraea and Commiphora myrrha. Phytochemistry 1982, 21, 677-680.

56. Maradufu, A.; Warthen, J. D. Furanosesquiterpenoids from Commiphora myrrh oil. Plant Sci 1988, 57, 181-184.

57. Manguro, L. O. A.; Mukonyi, K. M.; Githiomi, J. K. Bisabolenes and furanosesquiterpenoids of Kenyan Commiphora kua resin. Planta Med. 1996, 62, 84-85.

58. Joshi, S. C. Spectral characterization, stereochemical assignments and thermal rearrange- 
ments of naturally occurring furanogermacranes and furanoelemanes. J. Nat. Prod. Plant Resour., 2014, 4, 24-31.

59. Semnani, M. K.; Saeedi, M. Constituents of the essential oil of Commiphora myrrha (Nees) Engl. var. molmol. J. Essent. Oil Res. 2003, 15, 50-51.

6o. Amjad, A. M.; Mashooda, H. Chemical investigation of Commiphora mukul. Pak. J. Sci. Ind. Res. 1967, 10, 21-23.

61. Bhatt, D.; Jethva, K.; Zaveri, M. Cytotoxicity screening of the commonly used indigenous medicinal plants using brine shrimp lethality bioassay. Int. J. Pharm. Sci. Rev. Res. 2016, 37, 147-150.

62. Naidu, J. R.; Ismail, R.; Sasidharan, S. Acute oral toxicity and brine shrimp lethality of methanol extract of Mentha spicata L. (Lamiaceae) Trop. J. Pharm. Res. 2014, 13, 101-107.

63. Wu, C. An important player in brine shrimp lethality bioassay. The solvent. J. Adv. Pharm. Technol. Res. 2014, 5, 57, 58.

64. Gadir, S. A. Assessment of bioactivity of some Sudanese medicinal plants using brine shrimp (Artemia salina) lethality assay. J. Chem. Pharm. Res. 2012, 4, 5145-5148.

65. Saglam, H.; Arar, G. Cytotoxic activity and quality control determinations on Chelidonium majus. Fitoterapia, 2003, 74, 127-129.

66. Finney, D. J. Probit Analysis, 3rd edition, Cambridge University Press, London 1971.

67. Probit Analysis; Biostat for windows ver. 5.9.8.5; AnalystSoft.

68. General guidelines for methodologies on research and evaluation of traditional medicine. Geneva; WHO, 2000. p. 29-31. 